\title{
Kazuo Ishiguro's The Remains of the Day: A Historiographical Approach
}

\author{
Maha Abdel Moneim Emara ${ }^{1}$ \\ ${ }^{1}$ Department of English Language and Literature, Faculty of Arts, Ain Shams University, Egypt \\ Correspondence: Maha Abdel Moneim Emara, Associate Professor of English Literature, Department of English \\ Language and Literature, Faculty of Arts, Ain Shams University, Egypt. E-mail: maha_emara@yahoo.com
}

Received: September 9, 2015 Accepted: September 28, 2015 Online Published: November 29, 2015

doi:10.5539/ells.v5n4p8 URL: http://dx.doi.org/10.5539/ells.v5n4p8

\begin{abstract}
This paper attempts to analyze Kazuo Ishiguro's The Remains of the Day, in the light of various ramifications of postmodern critical historiographical approaches. It investigates the different narrative strategies Ishiguro uses to narrate historical events and dismantle objectivity mainly; backshadowing, intermixing of historical and personal incidents, and first-person unreliable narrator. Great deal of Ishiguro's text depth and complexity arises from the unreliability of the narrator whose narration presents several interpretive versions and controversial issues.
\end{abstract}

Keywords: Kazuo Ishiguro, postmodern historiography, The Remains of the Day, grand narratives, private and public reading, unreliable narrator

The representation of history is one of the major concerns of postmodernism. Postmodernist theorists have influenced Western historiography in their criticism and epistemological skepticism of traditional historiography as a reliable source of historical knowledge and truth, and as an objective discipline. For Claude Lévi-Strauss (1966), for example, the writing of history can never be objective because the historian necessarily has to be selective and choose from a "chaos of facts" (p. 257). In postmodernist historiography, the process of writing history utilizes narrative as the rhetorical device implemented in inscribing historical events. Postmodernist historiography presents an alternative perspective of historical narratives. To Hayden White (1987), history is "a narrative discourse the content of which is as much imagined as found" (p. 4). Jean Francois Lyotard goes so far as to emphasize that the crisis of representation has become the characteristic feature of the postmodern condition. The goal of the historiographer in postmodernist narrative is the revision of official records of historical events and the assumptions of 'grand narratives.' Accordingly, it is a revisionist history. Authors approach the narration of historical events in various ways and from different perspectives, therefore, it is difficult to reach the truth. Laurence Stone (1997) believes that:

historical truth is unattainable, and that any conclusions are provisional and hypothetical, always liable to be overturned by new data or better theories; ... that we are all subject to bias and prejudice because of our race, class and culture ... that documents ... were written by fallible human beings who made mistakes, asserted false claims, and had their own agenda. (pp. 120-121)

Postmodernist historiography conceptualizes historical events as discontinuous in the sense that they are isolated, nonlinear and do not follow a pattern of causality. Perez Zagorin (1999) sees that it would be impossible to paraphrase or summarize a work of history without altering its substance or meaning (p. 271). On his part, Gilles Deleuze (1983) says that we misrepresent the concept of eternal return if we believe it to be the return of the same. Instead, we should see eternal return as a cyclical process where events return to similar if referential events (p. 48) Postmodernist historiography seizes on dynamic system of history. It presents a new perspective of historical narratives, what Linda Hutcheon (1988) refers to as a return to history with a "new twist" (p. 26).

Since history is a complex concept, the understanding of any specific past event will always remain incomplete. In his discussion of this phenomenon in cultural discourses and cultural systems, Brian Ward (1996) states that historical events are assumed to encapsulate events in the past that determine events in the future (p. 9). However, in postmodernist historiography, future events cannot be predicted based on past events; what happens in the future is not contingent on what happened in the past. A postmodernist view of history "combines subjectivity 
and multiplicity, indeterminism, recursion, and a new chaotic view of language" (Ward, 1996, p. 9) embracing a 'Butterfly Effect', "which suggests that small or seemingly insignificant causes can lead to large and dramatic effects" (p. 10).

Narratives, like historical events, are shaped by a kind of a scenario qualified by 'The Butterfly Effect' implying that "if the same experiment is conducted a number of times, it is possible that different results will be attained each time. Small unnoticed factors, for example slight variations in the room temperature, will influence the outcomes of the experiment" (Ward, 1996, p. 10). Alternatively, the "Chaos Theory', developed in different ways by various critics (Ilya Prigogine, Barbara Riebling, Alexander Argyros, Hayles and Porush among others), Ward (1996) proposes that "the border between order and disorder is actually an area of complex organization, where order and disorder co-exist" (p. 10). Narratives categorized as historiographic present an 'indeterminate' view of history characterized by randomness, disorder and a nonlinear form and consistent with the paradigms proposed by 'The Butterfly Effect' and 'The Chaos Theory'.

In Kazuo Ishiguro's (b. 1954) The Remains of the Day (1989) [Henceforth referred to as The Remains], fictional narrative and history are closely connected. This paper analyzes Ishiguro's The Remains in the light of the critical theories of postmodern historiography. It investigates the different narrative strategies Ishiguro utilizes to narrate historical events and dismantle objectivity mainly; backshadowing, intermixing of historical and personal incidents, and first-person unreliable narrator. Significantly, the study endeavors to expand on James M. Lang's critical approach to Ishiguro's text and to develop the argument and line of thought in alternative directions.

The Remains is set in the fifties, in post-war England. In an interview with Graham Swift (1989a), Ishiguro justifies his choice of this period. He states:"I tend to be attracted to pre-war and post-war settings because I'm interested in this business of values and ideals being tested and people having to face up to the notion that their ideals weren't quite what they thought they were before the test came"'(p. 36).

History becomes increasingly relevant to the study of The Remains which embodies Ishiguro's vision of history and its inclusion in his fiction. It brings back to memory events that are familiar to many readers. Engagement with the question of history is Ishiguro's major preoccupation. Like several other writers concerned with history, he looks for location. In an interview with François Gallix (1999), he states: "We have a story and we look through our history books for a period and a place where this story could come to life" (p. 140). Besides, such concern involves other issues that he undertakes to explore; namely, "the messy, chaotic, undisciplined side. The undignified side" (Ishiguro, 1989c, p. 41). In an interview with Allan Vorda \& Kim Herzinger (1990), Ishiguro states, "I've not attempted to reproduce in an historically accurate way, some past period." To him, a crucial function of writing is to tackle, rework it and "undermine ... and use it in a slightly twisted and different way." He depicts a specific territory "somewhere between straight realism and ...fabulism .... But at the same time, it can actually prompt readers to say this isn't documentary or this isn't history or this isn't journalism” (pp. 74-75). Ishiguro goes further and adds:

Historians have to go about things in a certain disciplined way, they have to present evidence, they have to argue for their particular view of what happened in an academically disciplined environment. I'm under no such obligation; I can read history as a kind of location for my stories. Often I feel that is what I'm doing. I look at a certain time in history, because I think it would help to bring certain themes. (2001, p. 175)

In fact, the function of history and its purpose in serving culture and society is a focus of critical re-consideration. According to Zagorin (1999) Western society may be losing its connection to its past, yet it values history and believes it is important and this is apparent from the considerable resources it provides to support historical research and teaching (p. 273).

More recently, historical novels have reflected an interest in the ordinary and dispossessed both materially and politically. In The Remains, Ishiguro presents historical events from a marginalized point of view; or "history from below" (p. 279) as E. P. Thompson (1966) terms it. In the novel, official public and diplomatic history is contrasted with the private memories and reports of the diplomat's butler. According to Dominik LaCapra (1985), the past "arrives in the form of texts and textualized remainders - memories, reports, published writing, archives, monuments and so forth" (p. 128). The butler becomes therefore a point of departure in the analysis of the text since the character of the butler constitutes the axis of the text. It is through his memories and perspective that many of the historical events in the novel are filtered. Through the character of Stevens, Ishiguro engages with postmodern historiographic theory which reveals an increasing interest in the ordinary, private, and marginal lives and moments which according to James M. Lang (2000) "fill the long spaces between the historic battles, the treatise, the summits, and the incidents of public record" ( p. 151). The Remains formulates "a dialogue between the grand narratives of the war and the minor, subjective narrative of Stevens-between 
macronarratives of public history and the micronarratives of private memory" (Lang, 2000, p. 156). It makes out of Stevens a central consciousness of the narrative. The butler derives pride and dignity from doing something which to most people might look silly and trivial. He does not question the merits of his master, Lord Darlington. In an interview with Graham Swift (1989a), Ishiguro says; "The figure of the butler, the man who serves, someone who is so close and yet so very far from the hub of power would be a useful person to write through" (p. 37). The butler is a good metaphor for the relationship of very ordinary people to power. The Remains implements the use of traditional concepts like the unreliable narrator and objectivity to serve the purpose of creating a postmodern narrative of history. Such methods are manipulated to create a postmodern view of history and to parody the supposed objectivity of traditional historiography.

The focus is mainly on a marginalized figure from a British society searching for glimpses and snapshots of ordinary men and women. In interviews conducted with Ishiguro, he expounds at length his standpoint on this issue. He offers competing strategies of historicization, what Hayden White refers to as "competing narratives". Through the butler, an interest in the margins is reflected. The narrative moves away from conventional inscriptions of history, the grand narratives and grand characters of earlier historiography towards the lives and experiences of the ordinary, mundane, marginalized and dispossessed figures (Lang, 2000, p. 147). There is a rejection of the grand narrative tradition of historiography. The record of the historical event is compiled from the portraits of everyday life. The Remains is interested in narrative reconstructions of the lives of those individuals left to what Thompson (1980) has called "the enormous condescension of posterity." It relies on the tools of narrative paying close attention to "the rhythms of everyday life ... with greater attentiveness to those living on the social margins" (p. 12). Ishiguro opens up history to people who have been left out from the official records. Rejecting history which focuses on great men and their deeds, Michel de Certeau (1984) suggests that the historian should listen to the faceless and nameless subjects whom historians of earlier traditions ignored. He explains his interest in ordinary man's historical analysis:

The floodlights have moved away from the actors who possess proper names and social blazons, turning first toward the chorus of secondary characters, then settling on the mass of the audience. The increasingly sociological and anthropological perspective of inquiry privileges the anonymous and the everyday ... Slowly the representatives that formerly symbolized families, groups, and orders disappear from the stage they dominated during the epoch of the name. (p. v)

In this respect, Ishiguro's narrative texts - those set in the past and those in search of the past-feature characters who belong to the ordinary, the mundane and the dispossessed. Stevens, the butler of Darlington Hall is the ordinary man living under the shadow of the family and the name his master, Lord Darlington. Lang (2000) comments:

Stevens is one of the dispossessed - he is dispossessed, as a household servant, from the power he serves in the form of Lord Darlington. Indeed, Stevens thoroughly accepts and buys into his political disenfranchisement, arguing at several points throughout the novel that individuals like himself are incapable of contributing intelligently to the governance of the country. He parrots his employer's criticisms of democracy, and in one disturbing scene he willingly succumbs, at the behest of his master, to a humiliating demonstration of his own inadequacy to understand the nuances of world politics. (p. 150)

In the postwar era, historians and novelists experienced an interest in the marginalized and ordinary people. Stevens works behind the scenes, sacrificing his own interests and desires for those of the important individuals he serves. In an interview with Don Swaim (1990), Ishiguro justifies his choice of the butler as a figure occupying center stage in his narrative: "We hope that our little jobs will ... contribute to something ... What we do is we do our job, we work for an employer or organization or maybe some cause - political cause — and we just do a little thing. We hope that somebody up there, upstairs uses our little contribution in a good way. In other words we are like butlers" (p. 101). Stevens believes in his service of a man whom he thinks to be great; one who "does know all about these big things." He ruminates: "I can't make these big decisions about how we run the world. But I'll get some dignity from saying that I'm serving a master." He abandons his responsibility in contributing directly to political life, and the actual tragedy lies in serving "a Nazi sympathizer" (Ishiguro, 1990, $101)$.

The butler, Stevens, the central character of The Remains and Ishiguro's narrator, serves with extreme loyalty Lord Darlington who arranged unofficial meetings between British government officials and representatives of the German Nazi government. Much of Stevens' narration vindicates his blind submission to Lord Darlington even when the latter asks him to dismiss the two Jewish servants before the visit of The Nazi dignitaries. Though 
he himself is not totally convinced of his master's decision, blames Miss Kenton, the housekeeper, when she refutes Lord Darlington's decision and threatens to resign. Stevens addresses her:

'Miss Kenton, let me suggest to you that you are hardly well placed to be passing judgments of such a high and mighty nature. The fact is, the world of today is a very complicated and treacherous place. There are many things you and I are simply not in a position to understand concerning say, the nature of Jewry. Whereas his lordship, I might venture, is somewhat better place to judge what is for the best.' (pp. 157-158)

Throughout the novel, Stevens struggles to reconcile his own private memories of Lord Darlington and what seemed to Stevens Darlington's noble and virtuous intentions. He offers his private accounts of the international dealings taking place in Lord Darlington's home during the interwar years.

In fact, the narrative juxtaposes Stevens' narration of the making of world events as he overhears it in his Lords home, to public postwar perceptions of Darlington's role in the war. Stevens reflects:

It is important to be reminded moreover that although Darlington Hall was to witness many more events of equal gravity over the fifteen or so years that followed, that conference of March 1923 was the first of them...In fact, I often look back to that conference and, for more than one reason, regard it as a turning point in my life. For one thing, I suppose I do regard it as the moment in my career when I truly came of age as a butler...That conference was also memorable of course for other quite separate reasons, as I would like to explain. The conference of 1923 was the culmination of long planning on the part of Lord Darlington... one can see clearly how his lordship had been moving towards this point from three years or so before. As I recall, he had not been initially so preoccupied with the peace treaty when it was drawn up at the end of the Great War...but by the friendship with Herr Karl-Heinz Bremann. (Ishiguro, 1989c, pp. 73-74)

The choice of the butler is appropriate. The author accords him with the crucial task of reconstructing through his personal memories the social and political climate. Stevens' presence contributes to fill wide gaps in the incidents of public record through the eyes of ordinary and marginal lives.

In fact, the gaps between Stevens' private history and the public's historical record are comparable to the gaps in historical accounts of that of colonizer and colonized: between details of the subjugation of the colony and the picture of daily life of the colonized outside the power structures of the colony. In fact, the consequences of the gap between public and private memories impact the understanding of history and the narrative. Ishiguro's interrogation and critique is characteristic of historiographic practices. It produces a sense of indeterminacy in the Derridean sense which denies any final or determinate ending. Lang (2000) discusses this gap as responsible for conflicting impulses: "on the one hand, feeling narrative sympathy for Stevens and the external and internal restraints imposed on his character, on the other, feeling repugnance at the thought of the willing association he and his employer made with the Nazis" (p. 152). In scenes during which he meets with the small-town English citizens, he is committed to reconciling the apparent gaps between public history and his private perspective and memories of his past and that of his employer. Stevens works very hard to construct a portrait that reconciles both sides of Lord Darlington: the generous and as well as the traitor. Such contrast produces a sense of unease that Stevens tries to conceal with defensiveness of his sympathy with his master.

Ryan Trimm (2005) captures the story line of The Remains as linking Stevens' holiday journey in 1956 "with memories of personal tragedies occurring in the 1920s and 30s" (p. 136). Over the course of his journey Stevens realizes that the stability he felt in Darlington Hall has been utterly disrupted by the transformations occurring in Britain, its Empire as well as the world at large. Even his own position has been altered at Darlington Hall, at this point in time, Stevens is serving Mr. Farraday an American retiree and not the English lord. In The Remains, Stevens comments on Herr Bremann, the great German officer who used to visit Lord Darlington:

one could see at a glance that Herr Bremann was a gentleman of great decency. He returned again, having left the German army, at fairly regular intervals during the following two years, and one could not help noticing with some alarm the deterioration he underwent from one visit to the next. His clothes became increasingly impoverished, his frame thinner; a haunted look appeared in his eyes, and on his last visits, he would spend long periods staring into space, oblivious of his lordship's presence....I would have concluded Herr Bremann was suffering from some serious illness, but...his lordship[assured] me he was not so.(p. 74)

In fact, Ishiguro made out of Stevens a central consciousness of the narrative. He presents not only the major historical events but analysis of the great political figures from a marginalized point of view.

At any rate, both Lord Darlington and Stevens are products of historical contexts which they could not control. Stevens has always acted in accordance with the ideals of the socio-political climate at a given time. However, 
with the shift of climate and the prevalence of new set of ideals and public sentiment, Ishiguro's narrator finds that his actions needed re-evaluation. For the most part, Stevens' narrative consists of his attempt to recreate and/or vindicate, as an ordinary person removed from the ranks of decision-making, the historical context in which Lord Darlington, his employer to whom he bears great loyalty, made agreements and consorted with politicians. He endeavors to accommodate the public record condemning Darlington's immoral actions deference to Nazi diplomats. It is a persistence to delineate both poles of the man's personality: the noble and the publicly reviled Nazi sympathizer. As a literary and historical narrative, The Remains is complex. It is set in the summer of 1956, the year of the Suez Canal crisis which is regarded by many as the symbolic collapse of British imperial powers and ambitions. Although the momentous event is overshadowed in the text, Ishiguro's choice of such setting is definitely deliberate. Colonial politics and issues affect in a peripheral way the core of narration. (McCombe, 2002, p. 78)

A prominent characteristic practice of a historiographic approach is, as Michael André Bernstein (1994) labels it, historical "backshadowing", a literary practice that criticizes historical actors lacking the insight to foresee the future "which has become the historian's present or more recent past" (p.16). Bernstein explains that "[B]ackshadowing is a kind of retroactive foreshadowing in which the shared knowledge of the outcome of a series of events by narrator and listener is used to judge the participants in those events as though they too should have known what was to come"(p. 16). In the case of The Remains, backshadowing makes Stevens and Darlington guilty of not foreseeing catastrophic events and facilitating dialogue with Nazis. According to Bernstein, just as we experience the present moment as a potential window to different future scenarios, so too each past moment could have led to futures different from the currently experiencing (p.16). On his journey across the English countryside, Stevens encounters ordinary citizens who condemn Lord Darlington for not recognizing the extent of the atrocities perpetrated by his disastrous decisions. The public's perceptions of Darlington's character contrast starkly with Stevens' private opinions; he ruminates:

A great deal of nonsense has been spoken and written in recent years concerning his lordship and the prominent role he came to play in great affairs, and some utterly ignorant reports have had it that he was motivated by egotism or else arrogance. Let me say here that nothing could be further from the truth. It was completely contrary to Lord Darlington's natural tendencies to take such public stances as he came to do and I can say with conviction that his lordship was persuaded to overcome his more retiring side only through a deep sense of moral duty ... he was a truly good man at heart, a gentleman through and through. (Ishiguro, 1989c, pp. 63-64)

In the reports of conversations taking place in Lord Darlington's residence, Stevens reflects the precarious nature of diplomacy. After a three-day conference at Lord Darlington's home on the justice of the Versailles Treaty with Germany, Lord Darlington argued against the harsh conditions imposed on Germany by the Treaty. The force of this argument wins most of the participants of the conference, but not the American senator Lewis who pronounces his standpoint of Lord Darlington's activities, in a toast he offers during the dinner:

You gentlemen here....are just a bunch of naïve dreamers. And if you didn't insist on meddling in large affairs that affect the globe, you would actually be charming. Let's take our good host here...He is a gentleman... A classic English gentleman ... But his lordship here is an amature. ... He is an amature and international affairs today are no longer for gentlemen amateurs ... The days when you act out of your noble instincts are over. (Ishiguro, 1989c, p. 106)

Through Lord Darlington's response, Stevens paints a genuine diplomat. The former retorts to the toast in dignity; "What you describe as 'amateurism' sir, is what I think most of us here still prefer to call 'honour" (Ishiguro, 1989c, p. 107).

Lord Darlington's position is reviewed by David Cardinal, the young journalist who visits Darlington Hall prior to the outbreak of the war. Again he describes Lord Darlington as an amateur diplomat who lacks insight of changing rules of international relations. He explains to Stevens his viewpoint:

'His lordship is a gentleman. That's what's at the root of it. He's a gentleman, and he fought a war with the Germans, and it's his instinct to offer generosity and friendship to a defeated foe. It's his instinct. Because he is a gentleman, a true old English gentleman. And you must have seen it, Stevens ... The way they've used it, manipulated it, turned something fine and noble into something else-something they can use for their own foul ends?' (Ishiguro, 1989c, p. 234)

Stevens' master is swimming in deep waters and Cardinal believes he has been the most useful "pawn Herr Hitler has had in this country for his propaganda tricks" (p. 235). The implication of Senator Lewis and Cardinal's vantage point suggests that Lord Darlington is holding on to a lost historical ideal in which men of 
power believe they can settle international affairs through informal and honest deliberations. Lord Darlington considered the Nazi government like the British government; a power with which one can negotiate and reason.

While the grand narrative of public history places Darlington's actions in the commonplace collective story of the west's anti-Semitism, Stevens deploys his personal narrative to dispute and resist it. Lang (2000) depicts the conflict Stevens suffers as "an anxiety of grand narratives" (p. 162). Stevens experiences the predicament of opposing narratives as he works to reconcile the public perceptions of Darlington with his own private memories. Stevens can hardly recreate a historical context to explain and justify the ethical perspective of dismissing the Jewish employees. Lang (2000) observes that "Stevens certainly helps us to construct a more accurate historical context for Darlington's decisions," yet his concern is mainly "in excusing both Darlington and himself through that narrative construction" (p. 160). The sense of unease experienced by Stevens, torn apart between public historical account and Darlington's story, is imparted to the reader. Lang (2000) adds that; "While Stevens' personal redescriptions of Lord Darlington do suggest convincingly that we should be cautious in simply ascribing Darlington his fixed place in the public account, they also give evidence - through the vehicle of the unreliable narrator - that might cause us to doubt the reliability of his own narrative"(p. 162).

In fact, the two aspects of his narrative, reconstructing a historical context and offering excuses for his and Lord Darlington's behavior, are often intertwined. In one incident, Stevens discusses the visits of Ribbentrop to Darlington manor: "The truth is that Herr Ribbentrop was, throughout the thirties, a well-regarded figure, even a glamorous one, in the very best houses ... The great hypocrisy of these persons would be instantly obvious to you were you to see just a few of their own guest lists from those days" (pp. 144-145). Stevens links this critique of the forgetfulness of public memory, especially as it pertains to Ribbentrop's visits to Darlington manor, with the more sensitive issue of the dismissals of the Jewish girls. Eventually, the reader becomes accustomed to Stevens' strategies of narrative evasion and misdirection and thus less inclined to accept his reconstruction of Lord Darlington's actions.

It is interesting to note the intermixing of historical incidents and personal occurrences in his experience: the first occurs during the unofficial international conference of 1923, during which his father died. Stevens is able to maintain smooth household service at this conference despite his father's death. He claims that this incident "constituted a turning point in my professional development" (p. 114). The second turning point occurs when he cancels abruptly his evening meetings with Miss Kenton, thus damaging their slowly evolving personal relationships. He reflects; "It might even be said that this small decision of mine constituted something of a key turning point; that the decision set things on an inevitable course towards what eventually happened"(Ishiguro, 1989c, pp. 184-185). Turning points as such contribute to a coherent progression of events.

The Remains gives mixed signals about the accuracy of Stevens' historical reconstructions. This is conducive to a problem of truth. In fact, historical truth exists between two competing accounts of the past one public and one private. The interactions of grand and minor narratives; of public and private memory reflect "a cautionary attitude toward established public memory and a guarded faith in the ability of private memory to help recapture history in the face of public memory's backshadowings and historical revisions"(Lang, 2000, 163). Ishiguro's text highlights the way public record may situate the actions of Lord Darlington within the larger narrative of the war. Moreover, it reveals the inadequacy of public record when compared with the private memories of Stevens. His motivation to impose private memories derives from his desire to excuse his own and Lord Darlington's behavior. In order to contribute to a fuller understanding of the past, Stevens' private memories must engage in dialogue with the grand narratives of public memory and history.

In an interview with Gregory Mason (1989b), Ishiguro explains his interest in his first person narrators: "things like memory, how one uses memory for one's own purposes, one's own ends, those things interest me...deeply. And so, for the time being, I'm going to stick with the first person, and develop the whole business about following somebody's thoughts around, as they try to trip themselves up to hide from themselves"(p. 347). Stevens is the classically unreliable narrator. He continually reviews his recollection of significant incidents and sometimes admits that his memory of the events described in the novel is imperfect. "It is possible that this is a case of hindsight colouring my memory" (Ishiguro, 1989c, p. 90) ... However, I am not at all certain now as to the actual circumstances which had led me to be standing thus in the back corridor" (Ishiguro, 1989c, p. 222). In fact, The Remains is about unreliability as it is about the discrepancy between the public and private figures, and between dignity and the expression of emotion. Stevens' narrative unreliability emerges as means of demonstrating these unresolved conflicts. Lang (2000) regards Stevens' explanations and instability in narration with "a skeptical interpretive eye." Thus, "his reconstruction of an alternative historical context (is) a suspect one" (p. 160). The Remains, challenges, according to Kathleen Wall (1994), the definition of an unreliable narrator as one whose "norms and values" differ from the implied author. It questions the concept of an ironic 
distance between the biased narrator and the implied author who communicates with the reader behind the narrator's back (p. 18).

Unreliability is best understood as the distance between the "norms and values" of the author and those articulated by the narrator's words or behavior. Chatman (1978) suggests that the narrator's unreliability is a matter of misreporting events:

In "unreliable narration" the narrator's account is at odds with the implied reader's surmises about the story's real intentions. The story undermines the discourse. We conclude, by "reading out", between the lines, that the events and existents, could not have been "like that," and so we hold the narrator suspect. Unreliable narration is thus an ironic form....The implied reader senses a discrepancy between a reasonable reconstruction of the story and the account given by the narrator. Two sets of norms conflict, and the covert set, once recognized, must win. The implied author has established a secret communication with the implied reader. (p. 233)

On another plane, Rimmon-Kenan (1990) is more precise about how we identify unreliability; he maintains:

[When there is] a gap between the norms of the implied author and those of the narrator; when the facts contradict the narrator's views, the latter is judged to be unreliable ... when the outcome of the action proves the narrator wrong, a doubt is retrospectively cast over his reliability in reporting earlier events; when the views of other characters consistently clash with the narrator's, suspicion may arise in the reader's mind; and when the narrator's language contains internal contradictions ... [it leads to] undermining the reliability of its user. (p. 101)

Chatman (1978) depicts the conflict in the events that call into question what we are told about them. Susan S.Lanser (1981) observes that narration "can appear to be natural and innocuous or it can blatantly display its own artifice;" and note that the implied author must find a way of signaling the artifice of unreliability erected for his narrator (p. 101). Thus, an essential indication of the narrator's unreliability is found in the discourse of narration; the verbal habits of the narrator. The discourse itself offers clues to narrator's unreliability; it gives clues to habitual ways of thinking or of framing thoughts about the world of the story that might indicate biases or predispositions (Wall, 1994, p. 19).

According to Wall (1994), there are different kinds of unreliable narrators. There is the narrator who is motivated to lie to a narratee, implied or defined, and who may actually lie about events, or shape them to suit a vision of himself or herself that he or she wants the narratee to have (p. 22). However, there is a distinction between this benighted narrator and the narrator whose weakness is psychological. The latter lies to himself, also his subjectivity is due to so much conflict that he or she finds it necessary to bracket off portions of his or her experience. This kind of narrator includes commentaries, summaries and judgments that are at odds with events. Finally, there is the ordinarily unreliable narrator, "whose world view, predispositions, ignorance, or absent-mindedness determine in some way what he or she notices, and how he or she interprets certain situations"(Wall, 1994, p. 22). Like all human beings, most of the narrators fall into this category, though, as Wall suggests "we tend to find them more "reliable" if they seem aware of their biases, or struggle for such awareness, or if the implied author does not indicate that this human unreliability compromises the narration in some central and significant way"'(p. 22).

Some signs of Stevens' unreliability are verbal patterns that are contained in the discourse of which Stevens appears to be unaware. In fact Ishiguro has given his narrator a highly elevated diction that frequently serves to establish a distance between him and the reader. When Stevens feels a need to erase some part of himself, his shift from "I" to "one" is unfailing. This indicates a kind of dual identity or sensibility. Such a distancing is evident in his comment on his father about whom his feelings are ambiguous: "I realize that if one looks at the matter objectively, one has to concede that my father lacked various attributes one may normally expect in a great butler" (p. 35). Similarly the word "professional" becomes significant for the reader. Events quickly lead us to recognize the extent to which Stevens has constructed his life to fit a professional mold. Thus, the word 'professional' popping up every now and then, "becomes either a disguise for other, more emotional motives or a defense for his strangely unemotional behavior" (Wall, 1994, p. 24). Thus, he continually claims that his trip to see Miss Kenton has only professional motives, or that the impact of her departure from Darlington Hall would be felt only in the professional sphere, or that he inquires about her marriage only for professional reasons. In fact, Stevens uses 'professionalism' as "an excuse to shut out the messiness of life: sex, marriage, personal interest" (Shaffer, 1998, p. 76). He tries to repress everything related to his profession. Shaffer adds that the true nature of Stevens' idea of duty is nothing but "repression masquerading as professionalism" (p. 87). 
Stevens' evocation of a narratee is defensive. There is no physical presence in the novel to account for "you" that he frequently addresses. In fact, Ishiguro (1989c) makes Stevens say things like, "such great affairs will always be beyond the understanding of those such as you and me," (p. 209) or, "the likes of you and I will never be in a position to comprehend the great affairs of today's world, and our best course will always be to put our trust in an employer we judge to be wise and honourable, and to devote our energies to the task of serving him to the best of our ability" (p. 211). It is unclear to whom Stevens is speaking; it could be Miss Kenton the housekeeper, or any of the fellow servants or younger butlers, or it could be the ordinary English people he meets throughout the travel. Stevens could also be addressing the reader. According to Seonjoo Park (2008), Ishiguro invokes "the deep, immanent and simultaneous interconnection among Stevens, Miss Kenton, servants, ordinary people and readers all of whom exist in different places and temporalities, through this vague yet direct use of "you" (p. 66).

By endowing his narratee with knowledge, Stevens allows us to conclude the kind of listener he envisions: "a younger, less experienced butler who knows something of the procedures and problems that Stevens has encountered, who can make some judgments about the quality and circumstances of Stevens work, but who does not know as much as Stevens"(Wall, 1994, p. 24). His verbal exchange with this silent partner partaking in the conversation is followed by a justification of his behavior mainly, that the pronoun "you" automatically signals yet another moment of defensiveness. It is as if such a defense is necessitated by questions of the narratee that seem to voice Stevens' own uncertainties about his value and his career.

Another way to recognize Stevens' unreliability is through our perception of a conflict between the scenes he narrates and the interpretations that he gives regarding those scenes. We note that the feelings he reports conflict with his behavior; he fails to report reactions that other characters notice, or that the motives he attributes to himself or to other people are not consonant with the actions and behaviors arising out of those motives. His commentary is at odds with the evidence presented in the scene he comments upon.

This discrepancy between scene and commentary is largely due to the value Stevens places on the concept of dignity, a quality that requires him to repress any feelings that are not "professional," or that do not accord with his duty to his master. Stevens' introduction of the subject of dignity into what is appears like a travel narrative suggests that Ishiguro is asking us to question the motives for digression. The similarity that he finds between the "calmness of [the landscape's] beauty, its sense of restraint," (Wall, 1994, p. 25) and the question of what makes a great butler is forced. He dedicates six pages of his travelogue on the landscape and fifteen on the question of dignity which suggests preoccupation with this question. The restraint that the butler assumes when faced with a tiger under a dining room table, and the calm way in which his father deals with rude guests are admirable. Yet, the same virtues in another context are decidedly troubling. The restraint his father exercises during the visit of the general whose incompetence is responsible for the death of Stevens' brother is disturbing because it indicates a denial of personal feelings. At any rate, Stevens uses such modes of repression to derive his definitions of dignity and professionalism:

'dignity' has to do crucially with a butler's ability not to abandon the professional being he inhabits ... The great butlers are great by virtue of their ability to inhabit their professional role and inhabit it to the utmost; they will not be shaken out by external events, however surprising, alarming or vexing. They wear their professionalism as a decent gentleman will wear his suit ... It is, as I say, a matter of 'dignity'. (Ishiguro, 1989c, p. 43)

In fact, Stevens' speech is the basis of narrative unreliability. It highlights the repression of the personal and denial of significant aspects of the self. He adopts dignity as his primary value and abandons it when he is alone. This indicates that Stevens has attempted to avoid the needs of the feeling self, on the level of the narrative and on the level of his personal life. The emotional turmoil of the private man was not allowed to interfere with the duty and dignity of the public persona.

The conflict between the public and the private man - the analysis of the split self being a distinctive postmodern feature - appears in the contradiction between Stevens' presentation of scenes and his commentaries on such scenes which in turn highlights a vast split in subjectivity. After Miss Kenton receives notice of her aunt's death, Stevens recognizes that he has not "offered ... condolences." He maintains:

I could well imagine the blow the news would be to her, her aunt having been, to all intents and purposes, like a mother to her, and I paused out in the corridor, wondering if I should go back, knock and make good my omissions ... As it turned out, I did not see her again until the afternoon. ... I had preoccupied for some hours with the matter of Miss Kenton's sorrow, having given particular thought to the question of what I might best do or say to ease her burden a little. (Ishiguro, 1989c, p. 186) 
What follows in the narrative contradicts Stevens' proclaimed intentions. Instead of offering his condolences, Stevens reproaches Miss Kenton about the quality of work done by the young women in her charge and for her failure to supervise them properly. In spite of his kind intentions, he cannot find a way to talk about feelings of love or grief. In fact the sentimental romance reemerges only to be subverted. This is a typical postmodern practice; to establish in order to parody and subvert. One wonders if he is aware of the gap between his intentions and his behavior. Wall (1994) confirms that such "aporias obscure the dichotomy between the knowing and judging implied author and the benighted, unobservant narrator of the more traditional definitions of unreliable narration" (p. 26).

In fact, The Remains establishes a pattern of Stevens' conflict between the scenes he narrates and the interpretations that he gives to those scenes. Stevens offers no commentary or analysis of his feelings after his father's death. Instead, conscious that it is his duty to serve Lord Darlington guests, he asks Miss Kenton to close his father's eyes, and explains he must return to his important business. In no way does he openly express any grief to the narratee. Without comment from Stevens, his hidden grief is only observed by young Mr. Cardinal and Lord Darlington who ask if he is unwell or that it looks as if he's crying. Stevens simply replies that any emotion observed is merely the result of "the strains of a hard day" (Ishiguro, 1989c, p. 110). Moreover, his commentary substitutes the sense of loss that he might feel with a sense of professionalism:

Let me make clear that when I say the conference of 1923, and that night in particular, constituted a turning point in my professional development, I am speaking very much in terms of my own more humble standards. Even so, if you consider the pressures contingent on me that night, you may not think I delude myself unduly if I go so far as to suggest that I did perhaps display, in the face of everything, at least in some modest degree a 'dignity' worthy of someone like Mr Marshal — or come to that, my father.( Ishiguro, 1989c, pp. 114-115)

Similarly, when Miss Kenton announces that she is engaged and will be leaving Darlington Hall as soon as possible, Stevens in the scenes merely offers his congratulations. Cardinal, again, is the one who notices that he looks "unwell" (p. 220). Again Stevens claims that he is a little tired seeking to transmute his grief into calm composure:

At first, my mood was-I do not mind admitting - somewhat downcast. But then as I continued to stand there, a curious thing began to take place; that is to say, a deep feeling of triumph started to well up within me. I cannot remember to what extent I analyzed this feeling at the time, but today, looking back on it, it does not seem so difficult to account for. I had after all, just come through an extremely trying evening, throughout wish I had managed to preserve a 'dignity in keeping with my position' - and had so, moreover, in a manner even my father might have been proud of. (Ishiguro, 1989c, p. 238)

In fact, the scenes raise the question about the extent of Stevens' awareness of the information he gives us. Wall adds that through the tendency of others to notice his hidden emotions and grief, we hear the voice of the implied author who is responsible for managing such patterns. Stevens acknowledges his grief more precisely through the reports of others because "such reports will not violate our sense of dignity and decorum or will not tear the fabric that he has erected between his private and his professional selves" (Wall, 1994, p. 28).

Ishiguro's use of the first-person unreliable narrator creates the gap between what the narrator tells and what actually happens. Zuzana Fonioková (2006) says that since the narrator's utterance constitutes the only source of the reader's knowledge about the fictional world, "unreliable narration highlights the epistemological uncertainty and the impossibility of finding out a single, unchallenged truth" (p. 87). In this kind of narrative, the narrator's version of the story gets into conflict with another version, which is not narrated directly but the reader discovers it with the help of implicit additional information. Thus the tension between the stories that the narrators want to tell, and the one conveyed without intention gives the device of the unreliable narrator its meaning and value because it allows the reader to discover the plot. Fonioková (2006) adds that the reader does not always find out what really happens in the fictive world, since no "single correct version exists" (p. 87). In fact, inconsistencies related to Stevens' views about his profession draw attention to the use of an unreliable narrator but they also mask his feelings concerning the past.

The title of the narrative text is especially significant: The Remains of the Day symbolizes the late phase in Stevens' life during which he looked back at his past life. Renata Salecl (1994) highlights the link between 'remains of the day' and the Freudian 'day residues' (p. 15). According to Freud (1952), the unconscious processes of "dream-work" combine experience from the individual's waking life which cull memories and residues of the previous day to form dreams (p. 237). However, in a dream, the memories of the day as well as the wishes and thoughts appear disguised as something else (pp. 237-238). In the case of Stevens, recollections 
of the past correspond to the "day's residues," transformed by the narrator's unconscious into the story he represents.

Stevens' real journey has a metaphorical parallel in the trip his mind makes to the past. Fonioková (2006) observes that Stevens' recollections aim to refigure his past life; "one more acceptable to himself than his real life-story" (p. 89). Significantly, Stevens narrate his life in a way that conceals the "terrible mistake[s]" of his life imparting importance to his existence (Ishiguro, 1989c, p. 251). In order to achieve this goal, he omits some details of what happened and what he did in his life and stresses some other events, as mentioned earlier with reference to Strauss' idea that the writer of history should be selective; as selectivity precludes objectivity. Ishiguro comments on his narrator: "[Stevens] ends up saying the sorts of things he does because somewhere deep down he knows which things he has to avoid ... Why he says certain things, why he brings up certain topics at certain moments, is not random. It's controlled by the things he doesn't say. That's what motivates the narrative" (Shaffer, 1999, p. 8). In fact, it is not primarily the pronounced that makes up the story of Stevens' life, but the withheld facts that the reader finds between lines. "The apparent-told-version appears as a result of what the narrator hides" (Fionioková, 2006, p. 90). In this way, Stevens emphasizes his former employer Darlington's qualities as a noble gentleman and the butler's role in various dealings, and refuses to deal with Lord Darlington's proved, though well meant, support of the Nazi regime.

Stevens, the butler, represents the perfect manservant who eliminates all traces of his own personality as well as all individual dreams in the service of his master. The English butler is the dream servant who becomes, according to Meera Tamaya (1992), "the human robot with the "correct" accent, the "correct "manners" (p. 47). Stevens embodies the typical Englishness of butlers:

It is sometimes said that butlers only truly exist in England. Other countries, whatever title is used, have only manservants. I tend to believe this is true. Continentals are unable to be butlers because they are a breed incapable of the emotional restraint which only the English race are capable of... when we think a great butler, he is bound, almost by definition, to be an Englishman. (Ishiguro, 1989c, p. 44)

According to the British class system, every individual is expected to act out the role assigned to him/her at birth. One crucial element is the rigorous submission of the private self to the demands of the public persona. In Stevens' case, he is not only the son of a butler, but consciously strives to live up to the ideal of service achieved by his father. He narrates with great pride, a particular incident in his father's life which highlights the famed British self-restraint. Stevens' father is told by his master that a general who has been responsible for the unfair death of a large number of young men during the Boer war is expected for lunch. Among the victims was Stevens' brother, thus the master who knows about this tragedy offers Stevens' father a day off. However, the dutiful butler decides to carry on his duties and run the house party. Not only does he refuse but even volunteers to act as valet to the general, thus suffering "the intimate proximity for four days with the man he detests" (pp. 42-43). Tamaya (1992) observes that the irony of this self-abasement, is that neither Stevens nor his father question the worthiness of their sacrifices: "This blindness foreshadows Stevens' own colossal obtuseness as to his master's true moral stature" (p. 49).

Some of the most painfully ironic moments in the novel occur when Stevens lives up to the standards set by his father so well that he sacrifices his dying father's needs in order to ensure that Lord Darlington's dinner party runs smoothly. Summoned to his father's deathbed by the housekeeper, “Miss Kenton, please don't think me unduly improper in not ascending to see my father in his deceased condition at this moment. You see, I know my father would have wished me to carry on just now" (Ishiguro, 1989c, p. 111). As the assembled powerful guests feast and drink in elegant surroundings, Steven's father dies in a cell-like room.

Tamaya (1992) confirms that the brilliance of Ishiguro's narrative strategy is that just as "Lord Darlington has convinced Stevens of the importance and nobility of his diplomatic maneuvering, the intimate tone of the narrative beguiles the reader into a curious complicity with Stevens' point of view; this enables one to emphasize with Stevens even as the butler is completely taken in by Lord Darlington" (p. 50). Thus, Ishiguro makes it possible for the reader to experience the comic hoax which lies at the core of master/servant relationship. However, midway through the novel, the reader is alerted to the appearance versus reality fact. Mrs. Wakefield, a rich American anglophile, discovers that the solid monumentality of Darlington Hall, the manifestation in brick and stone of England's unbroken history of greatness is not a real thing. After examining a stone arch that frames the doorway to the dining room, Mrs. Wakefield comments that the arch "looks seventeenth century, but isn't it the case that it was built quite recently? ... It's very beautiful. But it is probably a kind of mock period piece done only a few years ago" (Ishiguro, 1989c, p. 129). In fact, just as Darlington Hall is a mock period piece, Lord Darlington's greatness seems fake. 
The truth about Lord Darlington is that he was actually a crypto Fascist, busily engaged in the appeasement of Hitler. Lord Darlington was influenced by Sir Oswald Mosley, the leader of the British Union of Fascists, and believes that the world should properly be divided into two classes: the strong and the weak, leaders and followers, masters and servants. He does not really subscribe to the notion that "the will of the people is the wisest arbitrator" on which the democratic process is founded (Ishiguro, 1989c p. 207). As he explains to Stevens: "Look at Germany and Italy, Stevens. See what strong leadership can do if it's allowed to act. None of this universal suffrage there" (p. 208).

At the end of the novel, Harry Smith, a farmer in Devon, restates the idea of England's greatness as the model of democracy:

And it's one of the privileges of being born English that no matter who you are, no matter if you're rich or poor, you are born free and you're born so that you can express your opinion freely and vote in your member of parliament or vote him out. That's what dignity's really about, if you'll excuse me, sir. (Ishiguro, 1989c, p. 196)

The main reason for Harry Smith's statement is that he mistakes Stevens for a well-to-do gentleman. Stevens encourages the mistake without lying by implying that he had met great politicians like Churchill and Lord Halfix.

Throughout the motoring trip, Stevens imitates the accent and manner that caused various people to mistake him for his master. In Devon, having run out of gas, he is offered hospitality by a simple farming couple. By a species of English bush telegraph, word spreads that a notable gentleman has landed in the village, and the farmers gather and question him avidly about his life and ideas. As always, like a good butler and a good Englishman, Stevens plays the role he is called upon to perform and expound on issues, such as the question of dignity. Harry Smith's democratic notion that "dignity is something every man and woman in this country can strive for and get" (Ishiguro, 1989c, p. 195) is undermined because he mistakes Stevens for a gentleman and that is the chief reason he takes Stevens' pronouncements seriously. He thus underscores, with comic irony, Stevens' own view, learnt from Lord Darlington that ordinary people may not be qualified to hold strong opinions.

Christine Berberich (2007) believes that Stevens' journey provides him with time not only to look around the glories of the English countryside, but also to think about his life, and opportunities both taken and missed. "Stevens' journey becomes a journey through his past and into his soul, which helps him realize how misconducted his life has been" (p. 141). In fact, Stevens never before met people as fellow human beings on an equal footing, always as social superiors or inferiors. At the end of his odyssey across England, Stevens recognizes, as the result of his unsettling experiences on the road, a devastating truth: "I trusted in his lordship's wisdom. All those years I served him, I trusted I was doing something worthwhile. I can't even say I made my own mistakes. Really —one has to ask oneself — what dignity is there in that?"(p. 256). Unexpectedly, the man who has spent much time asserting the importance of maintaining one's dignity and never revealing one's emotions in public, breaks down and weeps openly before a total stranger he meets on the pier at Weymouth.

As the sun finally sets on the British Empire, we expect Stevens to replace his unquestioning loyalty to one master with membership in the larger human community. However, as a means of experiencing human warmth, Stevens decides to learn the art of bantering, which his new master, Mr. Farraday, indulges in and which he means to expect his English butler to reciprocate. In fact, Stevens' attitude to bantering is typical to that of a butler. He visualizes it as a service he must perform to please his new employer: "It occurs to me, furthermore, that bantering is hardly an unreasonable duty for an employer to expect a professional to perform" (p. 258). Thus, Stevens will learn new tricks to perform for a new master. As he realizes the waste of his life in service to a discredited master, he prepares to devote the rest of his life to another. As he rationalizes; "The hard reality is, surely, that for the likes of you and I, there is little choice other than to leave our fate, ultimately, in the hands of those great gentlemen at the hub of this world who employ our services" (257). Stevens prepares to adjust himself to its rise on American shores. Tamaya (1992) comments that the "cruel hoax, the false consciousness, bred in the bones of generations caught in the vise of the class system, will not be eradicated by a single amount of anagnorisis" (p. 54). Trimm (2009) adds that the novel's ambiguous ending does keep the future open. The end has not yet been reached. Instead, "that end is what remains, what is waited upon; the evening (and the remains of the day) are just about to start" (p. 208).

In conclusion, a postmodern historiographic approach to The Remains of the Day (1989) presents a narrative that merges private and public history. Its depth and complexity arises from Stevens' own narration which, in both its form and its substance, presents several interpretive versions and controversial issues. By switching the viewpoint from the public to the private, the text lays out contrasting interpretations of the world-making events 
that underlie the narrative events. Due to his ignorance of world events and his unquestioning loyalty to Lord Darlington Stevens, the principle narrator, is severely restricted in his perception of the political forces dominating the period in which he lives. His versions of the experiences as he recalls and presents them, counter the version of public history. A retrospective interpretation of events through remembrance is juxtaposed to official accounts of history. It reveals that the negotiations between Ribbentrop and Lord Darlington are an underhanded act almost of treachery, not a matter of organizing a house party to perfection as Stevens remembers it. Truth lies somewhat, uneasily, between two competing accounts - public and private — of the past.

This paper has shown that The Remains (1989) is a good example of postmodern historiography. It is a history that acknowledges the contributions of both the private and subjective nature of memory as a parallel source for constructing and communicating a vision of the past. Ishiguro makes out of Stevens a central consciousness of the narrative to present not only the historical major events but analyzes them from a marginalized point of view. Yet, paradoxically he narrates the grand narrative by using an unreliable narrator. Stevens emerges as a metaphor for the relationship of ordinary people to power. Ishiguro privileges not the actual narrative but how the event is evaluated. In fact, it is not the pronounced that makes up the story of Stevens' life but the withheld and discerned between the lines. Thus, The Remains (1989), as has been illustrated, is a good example of postmodern engagement with history and reflects the response to the postmodern crisis of representation.

\section{References}

Berberich, C. (2007). A Pillar upholding nothing: Nostalgia, Englishness and the gentleman in Kazuo Ishiguro's The Remains of the Day. Image of the English gentleman in twentieth-century literature: Nostalgia and Englishness. London: Ashgate Publishing Group.

Bernstein, M. A. (1994). Foregone conclusions: Against apocalyptic history. Bekeley: University of California Press.

Chatman, S. (1978). Story and discourse: Narrative structure in fiction and film. Ilthaca: Cornell University Press.

DeCerteau, M. (1984). The practice of everyday life. (S. Rendall, Trans.). Berkeley: University Press of California.

Deleuze, G. (1983). Nietzsche and philosophy. (H. Tomlinson, Trans.). London: Athlone.

Fonioková, Z. (2006). The Butler's suspicious dignity: Unreliable narration in Kazuo Ishiguro's The Remains of the Day. Brno Studies in English, 32, 87-98.

Freud, S. (1952). A general introduction to psychoanalysis. (J. Riviere, Trans). New York, NY: Washington Square.

Hutcheon, L. (1988). A poetics of postmodernism: History, theory, fiction. London: Routledge. http://dx.doi.org/10.4324/9780203358856

Ishiguro, K. (1989a). Interview shorts: Kazuo Ishiguro. By Graham Swift. Conversations with Kazuo Ishiguro, pp. $35-41$.

Ishiguro, K. (1989b). An interview with Kazuo Ishiguro. By Gregory Mason. Contemporary Literature, pp. 335-347.

Ishiguro, K. (1989c). The Remains of the Day. Great Britain: Faber \& Faber.

Ishiguro, K. (1990, April). An interview with Kazuo Ishiguro. By Allan Vorda \& Kim Herzinger. Conversations with Kazuo Ishiguro, pp. 66-88.

Ishiguro, K. (1990, September). Don Swaim interviews Kazuo Ishiguro. By Don Swaim. Conversations with Ishiguro, pp. 89-109.

Ishiguro, K. (1999, December). Interview Kazuo Ishiguro: The Sorbonne Lecture. By François Gallix. Conversations with Kazuo Ishiguro, pp. 135-155.

Ishiguro, K. (2001, Spring). Like idealism is to the intellect: An interview with Kazuo Ishiguro. By Cynthia F. Wong. Conversations with Kazuo Ishiguro, pp. 174-188.

LaCapra, D. (1985). History and criticism. New York: Cornell University Press.

Lang, J. M. (2000). Public memory, private history: Kazuo Ishiguro's The Remains of the Day. Clio, 29(2), 143-165.

Lanser, S. S. (1981). The narrative act. Princeton: Princeton University Press. 
Lévi- Strauss, C. (1966). The savage mind. London: Weidenfeld \& Nicolson.

McCombe, J. P. (2002). The end of (Anthony) Eden: Ishiguro's The Remains of the Day and midcentury Anglo-American tensions. Twentieth Century Literature, 48(1), 77-92. http://dx.doi.org/10.2307/3175979

Park, S. (2008). Spontaneous mirth out of a misplaced respectfulness: A Bakhtinian reading of Kazuo Ishiguro's The Remains of the Day. Ariel: A Review of International English Literature, 39(3), 45-71.

Rimmon-Kenan, S. (1990). Narrative fiction: Contemporary poetics. London: Routledge.

Salecl, R. (1994). Love: Providence or despair. New Formations: Journal of Culture/Theory/Politics, 23, 13-24.

Shaffer, B. W. (1998). Understanding Kazuo Ishiguro. Columbia: University of South Carolina Press.

Shaffer, B. W. (1999). General Intoduction. In F. Gallix (Ed.), Lectures d'une ouvre: The Remains of The Day (pp. 5-11). Paris: Editions du Temps.

Shaffer, B. W., \& Cynthia F. W. (Eds.). (2008). Conversations with Kazue Ishiguro. Jakson: University Press of

Stone, L. (1997). History and postmodernism. The postmodernism reader. Ed. Keith Jenkins. London: Routledge.

Tamaya, M. (1992). Ishiguro's 'Remains of the Day: The empire strikes back.' Modern Language Studies, 22(2), 45-56. http://dx.doi.org/10.2307/3195017

Thompson, E. P. (1966, April). History from below. Times Literary Supplement, 7, 279-280.

Thompson, E. P. (1980). The making of the English working class. London: Victor Gollancz.

Trimm, R. S. (2005). Inside job: Professionalism and postimperial communities in The Remains of The Day. Literature Interpretation Theory, 16(2), 135-161. http://dx.doi.org/10.1080/10436920590946796

Trimm, R. S. (2009). Telling positions: Country, countryside, and narration in The Remains of the Day. PLL, 45(2), 180-211.

Wall, K. (1994). The Remains of the Day and its challenges to theories of unreliable narration. The Journal of Narrative Technique, 24(1), 18-42.

Ward, B. (1996). The chaos of history: Notes towards a postmodernist historiography. LIMINA, 2, 8-17.

White, H. (1987). The content of the form: Narrative discourse and historical representation. Baltimore: John Hopkins University Press.

Zagorin, P. (1999). History, the referent, and narrative: Reflections on postmodernism now. History and Theory, 38(1), 1-24. http://dx.doi.org/10.1111/0018-2656.731999073

\section{Copyrights}

Copyright for this article is retained by the author(s), with first publication rights granted to the journal.

This is an open-access article distributed under the terms and conditions of the Creative Commons Attribution license (http://creativecommons.org/licenses/by/3.0/). 